\title{
A Juridical Analysis of Death Penalty for Narcotics Abuse
}

\author{
Paras Setio \\ Master of Law of Universitas Gadjah Mada \\ Jl. Sosio Yustisia No. 1, Bulaksumur, Kab. Sleman, D.I. Yogyakarta 55281 \\ +6282390042438/parassetio@gmail.com
}

\begin{abstract}
Narcotics abuse is currently one of the biggest problems in Indonesia. The dangers posed by Narcotics Abuse have harmed the nation's young generation, therefore the Government continues to strengthen law enforcement regarding the issue of Narcotics abuse. The usage of narcotics is currently regulated in acts number 35 of 2009. In the acts, the government implements maximum sanction in the form of death penalty to certain categories of narcotics abuse. Until 2016, there were 55 perpetrators of narcotics related crimes who had been sentenced to death by Indonesian courts. This research aims to explore the judges' considerations as well as the obstacles they face in implementing death penalty to narcotics abusers. This research was conducted in the District Court of Magetan. Data was collected from primary and secondary data sources in the form of library studies and field studies. The sampling method used was purposive sampling to determine a judge of the District Court of Magetan who had sentenced narcotic abusers to death as the respondent. Furthermore, the approach of this research is sociological juridical approach. The collected data were analysed using qualitative descriptive method. This study reveals that the judges based their decision to pass death sentence on the act No 35 of 2009. In addition, the judge also took several juridical factors and sociological facts into considerations. The judge did not find any obstacles in passing death penalty because the case examiners agreed to impose death penalty.
\end{abstract}

Keywords: Judicial Analysis; Narcotics Abuse; Death Penalty

\section{A. INTRODUCTION}

In order to embody the prosperous, fair and wealthy Indonesian nation which is materially and spiritually evenly distributed under Pancasila (Five State Principles) and Constitution of the Republic of Indonesia 1945, the quality of Indonesian human resource as the national development resource should be continuously maintained and improved, including their health standards. Narcotics is one type of drug that is often used by medical professionals. However, rapid development of technology and information and the availability of certain types of narcotics lead many irresponsible individuals to abuse them.

Cannabis and methamphetamine are the two most popular drugs among narcotics abusers and despite the government efforts to eradicate them, the circulation of these drugs continues to grow rapidly. The drugs trafficking does not 
only involve domestic traffickers but also international syndicates. According to some experts, drug abusers are considered as victims of narcotics abuse crimes. From treatment point of view, this stance is justified. However, from criminal perspective, illegal drug users are considered as perpetrators of the crime, although it is required by the law that they will eventually be treated by doctors (Siswanto, 2009).

To solve the worrying problem of narcotics, Indonesian Parliament (DPR) has passed the act number 35 of 2009 Concerning Narcotics abuse. The act stipulates various types of sanctions for offenders, one of which, as stated in Article 113 and Article 114, is death penalty for the offenders with certain specifications. Meanwhile, as a country that uphold human rights, as contained in the 1945 Constitution, the implementation of death penalty has sparked heated debate in Indonesia. On one hand, Indonesia upholds the values of human rights, on the other hand Indonesian legal products still include articles that enable capital punishment which considered by many activists as a violation of human right (Waluyadi, 2009: 57).

In the Indonesian constitution, the issue of human rights is elaborated from article 28A to article 28J of the 1945 Constitution. Article 28A through 28I regulate the rights of Indonesian citizens while article 28J deals with their responsibilities namely the responsibility to respect the rights of others. Furthermore, the Supreme Court Ruling Number 2-3/PUU-V/2007 explained that the implementation of capital punishment does not conflict with the Constitution. Therefore, passing death penalty to narcotics abusers do not violate human rights. Moreover, the perpetrators are considered to be criminals who have violated the rights of other citizens, especially because their crimes have harmed the younger generation. Nonetheless, the implementation of death penalty in Indonesia is highly selective.

Narcotic drugs that were initially developed to be used by medical professionals and researchers, are now being abused by some irresponsible people. According to data from the National Anti-Narcotics Agency, throughout 2017 the National Anti-Narcotics Agency and Customs have handled 43,000 cases of narcotics abuse involving 50,000 convicts. The large amount of narcotics abuses in Indonesia lead to the mushrooming number of dealers and narcotics couriers. Up to this year, there were 55 people who had been sentenced to death by the court in drug related cases (Ravel, 2018).

The problem of narcotics abuse in Indonesia is very worrying. The victims involved in narcotics abuse are the groups of people who are still in their productive age. Therefore, narcotics abuse does not only have harmful impacts on the users but also on their families. The domino effect of narcotics misuse damages the victim's nerves system causing them to commit crimes and succumbed into various social and domestic problems. Accordingly, narcotics abuse has been linked to other 
crimes and social problems such as domestic violence, theft, divorce and even murder.

This study seeks to explore the considerations took by the judge in passing death penalty on the perpetrators of narcotics related crimes. Furthermore, this study also investigates the obstacles the judge face in the process of imposing the capital punishment.

\section{B. RESEARCH METHOD}

This research employs descriptive qualitative method in its analysis, which means this method is seeking the meaning or the understanding of certain phenomena or cases, directly or indirectly holistically. Furthermore, using this qualitative as a method means employing narrative arrangement, rather than numerical (Yusuf, 2014). This study will focus on examining the data collected from Judges decisions of two District Court both are Magetan (East Java) and Stabat (North Sumatra), and the interview with a judge who has passed capital punishment. The approach used in this study is sociological juridical approach with the aim to examine the act No. 35 of 2009 concerning Narcotics and its implementation in the District Court of Magetan. The object of the study is a juridical analysis of the application of dead penalty for narcotics abusers. The sources of data in this study include court decisions in narcotics abuse cases with capital punishment in the District Court of Magetan and through interviews with judges who have passed death penalty on convicts of narcotics abuse cases in the District Court of Magetan.

The data used in this study are comprised of primary data and secondary data. The primary data are the documentation of judge's decision in the District Court of Magetan and Stabat, and also the data gathered in the interviews with Magetan Court Judges. Meanwhile, the secondary data are obtained from literature sources including books and relevant journals.

\section{DISCUSSION AND ANALYSIS}

\section{Judge's Considerations in Passing Death Penalty on Perpetrators of} Narcotics Abuse

As a legal state, Indonesia should be consistent in enforcing the law. Furthermore, Indonesian Constitution has guaranteed several fundamental rights that cannot be violated under any circumstances, especially the right to life (Piktor, 2016). The right to life is a non-derogable right, therefore, implementing death penalty would cause dilemma (Anjari, 2015). Despite the controversy surrounding the implementation of death penalty, in the reality of formal juristic, capital punishment is indeed justified. There are several articles in Indonesian Criminal Code that contain capital punishment (Waluyo, 2008). 
The implementation of capital punishment on perpetrators of narcotics abuse in the Stabat District Court was executed in the case number 208/Pid.Sus/2015/PN.Stb. Before passing the judgement, the case examiners carefully consider the charges put forward by the Prosecutor. In that case, the Prosecutor put forward alternative charges or mutually exclusive charges consisting of several articles. The first alternative charge was based on Article 114 paragraph (2), the second charge was based on Article 115 paragraph (2), while the third charge was based on Article 112 paragraph (2) letter a. Law No. 35/2009.

The trial process began with the prosecutor reading the indictment, then the accused's lawyer read his Memorandum of Defense, finally the Judges passed the verdict. In making the verdict, the Panel of Judges considered several matters; Firstly, the Judges examines the elements of the article 114 paragraph (2) of Act No. 35 of 2009 as the basis of the indictment put forward by the Prosecutor. The paragraph reads as follows:

"In case of the action to offer to be sold, sell, purchase, being intermediary within transaction, exchange, deliver or receive Narcotics Group I as referred to in paragraph (1) thereto which in form of the plant the weight exceeding 1 (one) kilogram or exceeding 5 (five) trees or not in form of plant the weight exceeding 5 (five) grams, the perpetrator shall be sentenced to death, or imprisonment for life, or imprisonment minimum 6 (six) years and maximum 20 (twenty) years and penalty maximum as referred to in paragraph (1) there to plus $1 / 3$ (one third)"

The article 114 paragraph (2) of the Act No. 35/2009 contains three elements;

a. The first element is "any person"

b. The second element is "not entitled or against the law"

c. The third element is "Offering to be sold, sell, purchasing, being intermediary within transaction, exchange, deliver or receive Narcotics Group not in form of plant the weight exceeding 5 (five) grams

The trial revealed that the defendant's action fulfils these three elements in the first alternative indictment, therefore the defendant could be punished. Furthermore, the Judges also examine the personality and the deed of the defendant in order to identify justifications or excuses that might remove the charges. Excuse defence is when the defendant's action is still considered to be a criminal act but believes that he or she cannot be held responsible because there was no criminal intention. Whereas justification defences eliminate the illegal nature of defendant's actions so that their actions were justified (Moeljatno, 2008). The judges concluded that there was no excuse nor justification that could eliminate the charges put forward by the prosecutor. Therefore, the defendant must be held responsible for his actions. Additionally, the judges also considered whether passing death penalty on the defendant is a violation of human rights or not. 
In addition to considering the elements of the article indicted by the prosecutor, excuses or justifications, and human rights, the judge also examined factors that could incriminate or exonerate the defendant. In this case, the first factor that incriminated the defendant was his action that hamper government's program to combat narcotics abuse, the second factor is that his actions harmed the younger generation and the third factor is the fact that he is a member of an international drugs trafficking syndicate.

Furthermore, in accordance with the principle in the application of capital punishment, before passing death penalty, the factor which could exonerate the defendant must be proved to be non-existent. In this case, the judge concluded that the involvement of the defendant in drugs trafficking is an incriminating factor, therefore the defendant could be sentenced to death.

The judge's consideration in passing death penalty on the perpetrator of narcotics abuse is in accordance with the sense of justice. The judge had carefully examined all the facts that were revealed at the trial, including the testimony of the witnesses, the statement of the defendant, and all the evidences. Moreover, imposing capital punishment on the perpetrators of narcotics abuse will have a deterrent effect.

The judges assert that imposing capital punishment on the perpetrators of narcotic abuse is not a violation of human rights and do not go against the Constitution. There are 50 people die every day because of narcotic abuse. Accordingly, the judges argued that instead of violating human rights, capital punishment would protect the human rights of others. Moreover, the judges consider narcotics abuse as an extraordinary crime that harms the life of many people and have abhorrent social and economic impacts. The rampant distribution of illicit drugs, especially amphetamine (meth) is worrying. Therefore, taking serious action against narcotics related crimes is imperative (Decision Number 208/Pid.Sus/2015/PN.Stb.).

Before passing death penalty, the panel of judges is required to consider three fundamental aspects, namely the philosophical, juridical, and sociological foundations of death penalty. The philosophical basis requires the judges to examine the implementation of capital punishment in light of the human rights and constitutional theories. The juridical basis requires the judge to look into the question of conformity between the acts that contain capital punishment with the Constitution. Considering the sociological basis means that the judge must be aware of the existing debate on the implementation of death in the society. Additionally, they must also provide reasons to pass death sentences (Iriani, 2016).

Finally, the judge must consider all possibilities that might occur after the completion of the death penalty. Supposed a person has been convicted and then executed but later on newly found evidence reveal that he is innocent, then no 
further effort can be made in term of rehabilitation because the convict is dead. Thus, in implementing capital punishment the judges are required to be exceptionally thorough and careful in examining the case.

\section{The Obstacles Faced by the Judge in Passing Death Penalty on the Perpetrators of Narcotics Abuse}

Mors dictur ultimum supplicium: capital punishment is the most severe punishment. Death penalty is designed as a form of punishment for violent and immoral criminals, it is carried out by the state as a representation of the victims (Hiariej, 2014). In implementing capital punishment, the Judges face juridical and non-juridical obstacles. The juridical factors closely relate to the theories of the purpose of punishment. In the draft I of the Book of the National Criminal Code compiled by LPHN, it was formulated that the purpose of punishment is to prevent criminal acts and to guide convicted persons to become good members of society and to eliminate the blemishes of criminal acts. In addition, punishment is not intended to torment and is not permissible to demean human dignity (Piktor, 2016).

From juridical point of view, there are two contradicting juridical bases, on one hand the Opening of the 1945 Constitution, Article 28 of the 1945 Constitution, as well as the Universal Declaration of Human Rights grant anyone the right to life. On another hand, article 10 of the National Criminal Code establish several forms of punishment for criminal acts, including death penalty. This juridical contradiction has been resolved by the Constitutional Court in the decision number 2/PUU$\mathrm{V} / 2007$ and number 3/PUU-V/2007.

Death penalty is justified in Indonesian legal norms since the perpetrator of the crimes that have been specified in act No. 35/2009 has violated or undermine the rights of other people. Therefore, according the provisions of Article 28J of the 1945 Constitution, the state has the authority to revoke his/her human rights. The article establishes that in exercising their rights and freedoms everyone must submit to the restrictions stipulated by law for the sole purpose of guaranteeing and respecting the rights and freedoms of others and to fulfil just demands in accordance with moral considerations, religious values, national security and public order in a democratic society.

The Constitutional Court considers the permissibility of capital punishment on the basis of Article 6 Paragraph (2) of the ICCPR which explains that the imposition of capital punishment can be carried out on the most serious crime in accordance with the law at the time of the crime, in the realistic approach the ICCPR never explicitly prohibits capital punishment (Arie, 2009: 15). Currently narcotics abuse is a very/ serious crime in Indonesia, so the imposition of capital punishment can be applied to perpetrators of narcotics related crimes. From human rights perspective, it is possible for a country to impose capital punishment, even with restrictions. The 
right to life is not absolute and capital punishment should not be contested with the right to life as a non-derogable (Toule, 2013).

Indonesian legal system follows the Absolute Theory (Vergeldingstheorie) which considers the sentence as a retaliation for the perpetrators who have caused misery to other members of society (Marpaung, 2005). Furthermore, the absolute theory suggests that the punishment is carried out solely for retaliation. Adherents of this theory include Emmanuel Kant, Hegel, Nigel Walker, Pompe, Polak, and Herbart. This theory assumes that the crime must be repaid and the person committing the crime must feel the same suffering as what the victim feels. Thus, it is the crime that determines the severity of the punishment (Arianti, 2011).

From a juridical point of view, the Constitutional Court is indeed the official interpreter of Indonesian criminal code. However, the current development of the theory of the purpose of punishment recognizes a combined theory which is an amalgamation of absolute theory with relative theory. The Combination theory asserts that instead of seeking revenge, punishment has several purposes including prevention, deterrent, maintaining public order, and rehabilitating the convicts. Punishment is considered as the last resort (ultimum remidium) (Soesilo, 1995). Hence, there is a conflict between the juridical reality of Indonesia and the current theory of punishment. Indonesian juridical system assumes that capital punishment is the best way to reduce criminal acts, whereas from the theoretical point of view the punishment is not a revenge, instead, the retaliation is a mean of protecting the interests of the community.

In terms of non-juridical, the application of capital punishment has risen many criticisms. The first critic of capital punishment was Casare Beccaria who argued that capital punishment harms the community and produces savagery. At the international level, there have been many attempts to eliminate capital punishment for the last 50 years, including the provision of the right to life in the United Declaration of Human Rights (1948) and the United Nations Covenant on Civil and Political Rights (1966). According to Amnesty International, more than 100 countries have abolished capital punishment, some abolished it for all types of crimes while some other abolished it for ordinary crimes and still apply it for extraordinary crimes (Hiariej, 2014).

Article 14 paragraph (1) of the United Nations Covenant on Civil and Political Rights (ICCPR) states that:

"All persons shall be equal before the courts and tribunals. In the determination of any criminal charge against him, or of his rights and obligations in a suit at law, everyone shall be entitled to a fair and public hearing by a competent, independent and impartial tribunal established by law. The Press and the public may be excluded from all or part of the trial for reasons of morals, public order or national security in a democratic society, or when interest of the private lives of the parties requires, or to the extent 
strictly necessary in the opinion of the court in special circumstances where publicity would prejudice the interests of justice; but any judgment rendered in a criminal case or in a suit at law shall be made public except where the interest of juvenile persons otherwise requires or the proceedings concern matrimonial disputes or the guardianship of children"

In the Indonesian context, many recent critics of death penalty argue that only God has the right to take lives, therefore death penalty must be abolished (Marpaung, 2005). Meanwhile, human rights advocate such as the National Human Rights Commission (Komnas HAM) has continued to further the narrative that death penalty goes against the 1945 Constitution which explicitly stated that the right to life cannot be undermined for any reason (Prabowo, 2015).

International critics such as Amnesty International have criticized the implementation of death penalty in Indonesia. Amnesty International insists that death penalty violates basic human rights, namely the right to life. Furthermore, they also argue that it is a "cruel, inhuman and humiliating punishment." Their criticism is not only about the methods of execution, but also about the long wait and mental suffering of the death row inmates. The United Nations states that drug trafficking and smuggling are not actions that can be sentenced to death according to international standards. Apart from the criticism from the UN and Amnesty International, Indonesian government also face strong criticism from the international community who demand death penalty to be abolished throughout the world (Lucas, 2015).

To conclude, in implementing capital punishment against the perpetrators of narcotic related crimes, the judge faced both juridical and non-juridical obstacles. The judge had to deal with the juridical contradiction between the existing juridical system that adheres to Absolute Theory that assumes punishment as a retribution and recent theory of punishment, namely the Combination theory that do not regard punishment as a retribution but rather a mean of rehabilitation and protection of public order. Meanwhile, the judge also faced criticism and opposition from various parties including Amnesty International, the United Nations, the National Human Rights Commission and other people who consider capital punishment as a violation of basic human rights, especially the right to life that should not be undermined for any reason.

\section{CONCLUSION}

Before passing death penalty, the judge took into considerations several factors, firstly he examined the elements of Article 114 paragraph (2) of Act Number 35 of 2009 as the basis of the charges put forward by the prosecutor. The trial revealed that the defendant's actions fulfilled all the elements of the article. Secondly, the judge considered the excuses and justifications that might remove the charges. Thirdly, the judge considered whether passing death penalty violates the 
defendant's human rights or not. Fourthly, the judge considered all factors that might exonerate and incriminate the defendant.

The obstacles faced by judges in imposing capital punishment consist of juridical and non-juridical factors. The juridical factor is the existing contradiction between the purpose of punishment in Absolute Theory as the basis of current juridical system and the emerging Combination theory. The emerging theory emphasize the importance of the reparation of the perpetrators over retaliation, while the absolute theory regard punishment as retaliation against them. According to the absolute theory, imposing capital punishment on the perpetrators of narcotics-related crimes is considered relevant because it provides a deterrent effect. Meanwhile, the non-juridical factor is the fact that capital punishment has been object of criticism from the international community, especially human rights activists.

The researcher suggests that the implementation of death penalty against the perpetrators of narcotics abuse is still needed in Indonesia, as a deterrent to other would-be offenders. However, the researcher also suggests that the capital punishment should not be the main punishment as in Article 10 of the Criminal Code, but as an alternative punishment. This mechanism would provide a chance to rehabilitate the offenders in accordance with the purpose of punishment in the Combination Theory.

\section{REFERENCES}

Anjari, W. (2015). Penjatuhan Pidana Mati di Indonesia Dalam Perspektif Hak Asasi Manusia. Widya Yustisia, 1(2).

Arianti, A. T. (2011). Mengartikan Pelanggaran HAM Berat Dalam Hk Asasi Manusia Indonesia. Jurnal AMANNA GAPPA, 19(3), 251-269.

Hiariej, O. S. E. (2014). Prinsip-Prinsip Hukum Pidana. Yogyakarta: Cahaya Adma Pustaka.

Iriani, D. (2016). Kejahatan Narkoba: Penanggulangan, Pencegahan dan Penerapan Hukuman Mati. Justicia Islamica, 12(2).

Lucas, G. (2015). Hukuman Mati Harus Dihapus Total | DUNIA: Informasi terkini dari berbagai penjuru dunia | DW | 28.04.2015. Retrieved July 3, 2018, from https://www.dw.com/id/hukuman-mati-harus-dihapus-total/a-18414305

Marpaung, L. (2005). Asas Teori Praktik Hukum Pidana. Jakarta: Sinar Grafika.

Moeljatno. (2008). Kitab Undang-Undang Hukum Pidana (KUHP). Jakarta: Bumi Aksara.

Piktor, A. (2016). Hukuman Mati Bagi Pengedar Narkotika Dalam Konteks UU No. 22 Tahun 1997 dan Perubahan UU No. 35 Tahun 2009. Lex Administratum, IV(3), 181-188.

Prabowo, D. (2015). Penghapusan Hukuman Mati Dinilai Tak Perhatikan Aspirasi Masyarakat - Kompas.com. Retrieved July 16, 2018, from https://nasional.kompas.com/read/2015/09/14/21083061/Penghapusan.Hu kuman.Mati.Dinilai.Tak.Perhatikan.Aspirasi.Masyarakat

Ravel, S. (2018). Sepanjang 2017 BNN, Polri, dan Bea Cukai Ungkap 43.000 Kasus Narkoba - Kompas.com. Retrieved July 3, 2018, from https://megapolitan.kompas.com/read/2018/01/19/16355031/sepanjang- 
2017-bnn-polri-dan-bea-cukai-ungkap-43000-kasus-narkoba Siswanto, A. (2009). Pidana Mati dalam Perspektif Hukum Internasional. Refleksi Hukum.

Soesilo, R. (1995). Kitab Undang-Undang Hukum Pidana (KUHP). Bogor: Politeia.

Toule, E. R. M. (2013). Eksistensi Ancaman Pidana Mati Dalam Undang-Undang Tindak Pidana. Jurnal Hukum Prioris, 3(3), 103-110.

Waluyo, B. (2008). Pidana dan Pemidanaan. Jakarta: Sinar Grafika.

Yusuf, A. M. (2014). Metode Penelitian Kuantitaif, Kualitatif, dan Penelitian Gabungan. Jakarta: Kencana. 